\title{
Influence of failures of overhead lines on reliability of autonomous power supply system
}

\author{
Dmitriy Karamov, Sergey Perzhabinsky ${ }^{1}$ \\ Melentiev Energy Systems Institute of SB RAS, Irkutsk, Russia
}

\begin{abstract}
We research influence of failures of overhead lines on reliability of autonomous power supply system with distributed generation in the given article. Simulation of failures of overhead lines are done on the base of long-term data of exploitation distributing electricity networks. Considered autonomous power supply system consists of wind and solar power stations. Diesel generators are emergency sources of electricity in the system. For adequacy estimation of electricity supply we many times simulated and analyzed of random states of autonomous power supply system. Results of experimental research confirm that detailed accounting of statistics of real failures of overhead lines increases of quality of reliability analysis.
\end{abstract}

\section{Introduction}

Autonomous power supply system with distributed generation have similar classification features with traditional rural electricity networks. Rural overhead lines of electricity supply with voltage $10 \mathrm{kV}$ are subjected to influence of a set of external factors decreased of reliability level of electricity supply. Crashes of high-voltage insulators, switches and others constructive components are the basic reasons of initiation of failures of power lines [1].

Overhead lines are one of the basic elements of electricity networks of autonomous power supply systems with renewable sources. Estimation of their crashness on a base of real data allows essentially to increase of effectiveness of electricity supply on their project stage.

We research influence of failures of overhead lines on reliability of autonomous power supply system with distributed generation in the given article. The object of our research is autonomous power supply system with wind and solar power stations. Wind and solar power stations connect with a customer by overhead lines with voltage $10 \mathrm{kV}$. Two diesel generators are emergency sources of electricity in the system. Simulations of failures of overhead lines are done by Monte Carlo method on the base of long-term statistics of crashes of overhead lines in the considered region. We analyze reliability of electric power system according to method [2]. Crash indexes for network and generating equipment are traditionally used in researches of reliability of electric power systems. These indexes are taken from technical documentation and reference data. Applying of real statistical data of failures of network equipment will allow to increase of validity of reliability indexes.

The article consists of 3 main section, introduction and conclusion. The second section is devoted by results of research of reasons of failures of overhead lines through the example of electricity networks in Norway. The third section contains a description of elements of method of adequacy analysis of electricity supply. The results of experimental research are presented in the fourth section.

\section{Analysis of failures of overhead lines in power supply system}

Analysis of indexes of failures of electricity networks allows to find a set of specialties and dependencies connected with conditions of their exploitation. Annual statistical reports of energy companies have a biggest practical and scientific importance [3].

As an example we'll consider a basic indexes of failures in electricity networks of Norway. Our research will be based on data from annual reports with results of estimation of events which induced outages of electricity supply in the considered electric power systems.

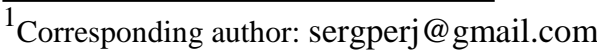


Today the length of Norway electricity networks with voltage less than $22 \mathrm{kV}$ composes about 59 thousand of kilometers. The processing of annual reports presents that the total amount of failures of Norway overhead lines is situated in limits from 8793 to 13456 units in a year [4]. The total amount of failures relative every month and year (from 2007 to 2016) are presented on the fig. 1 .

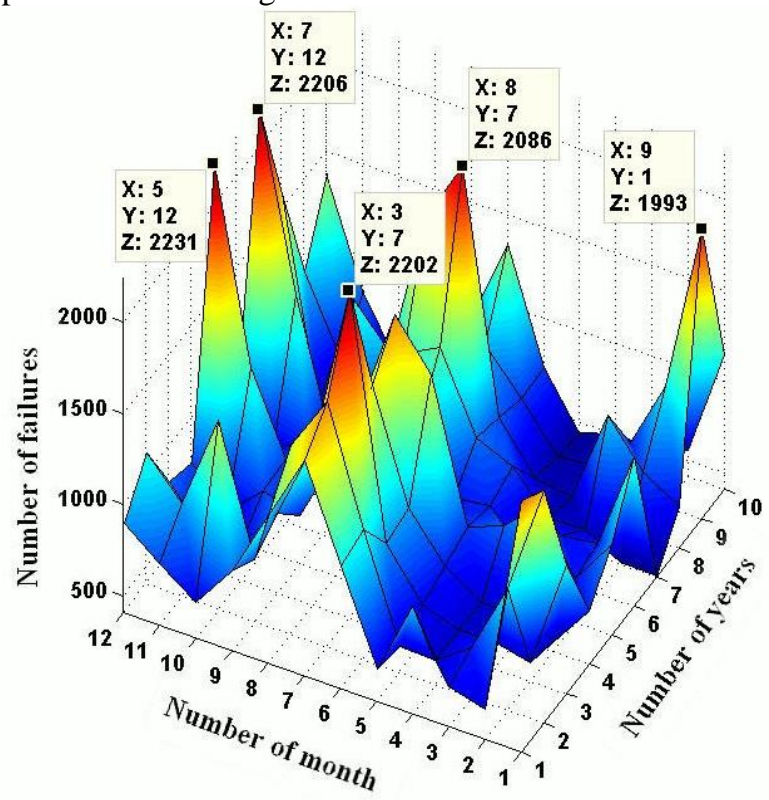

Fig. 1. The number of overhead power line failures for each month and year of the considered period (2007-

2016) in electric networks of Norway

As you can see from the fig. 1 the biggest amount of failures is observed in the summer and winter periods. The basic part of power outages connects with natureclimatic changes in these periods such as thunderstorm activity, wind load, ice, pollutions, crashes induced by flora, birds and animals [5].

The reasons of failures of overhead lines are presented in percentage ratio on the fig. 2 .

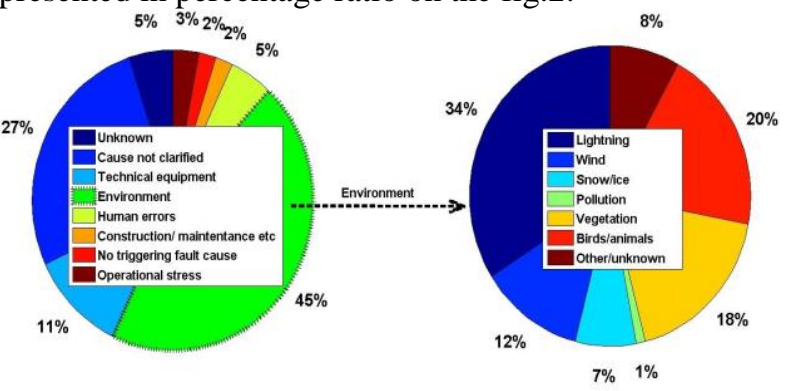

Fig. 2. Diagram of overhead line failures in electricity networks up to $22 \mathrm{kV}$ in Norway

It is important to note about third part of failures cannot be classified. Herewith half of no classified failures connects with combinations of nature-climatic influences.

Analysis of statistics of damaging of overhead power lines in Siberian Federal District of Russia shows that main reason of failures of overhead lines with voltage $10 \mathrm{kV}$ is short between phases as a result of wind load [6]. This kind of crashes composes from $35 \%$ to $44 \%$ from all failures of overhead lines with voltage $10 \mathrm{kV}$. Consequences of ice and thunderstorm activity are additional mechanical loads on overhead lines in the given region. As well as failures of overhead lines with voltage $10 \mathrm{kV}$ took place because of a reason of destruction of insulators. This kind of crashes composes from $24 \%$ to $35 \%$ from all failures of overhead lines with voltage $10 \mathrm{kV}$ in the considered region [7].

\section{Algorithm of analysis of reliability of electricity supply}

Results of researches of reliability of electricity supply of traditional electric power systems are presented in the works [2]. Issue of reliability of electric power systems with renewable sources have studied in a less degree. It is connected with difficulties of modelling of environmental conditions in the region $[8$, 9].

Let's consider the scheme of autonomous electric power system presented on the fig. 3 .

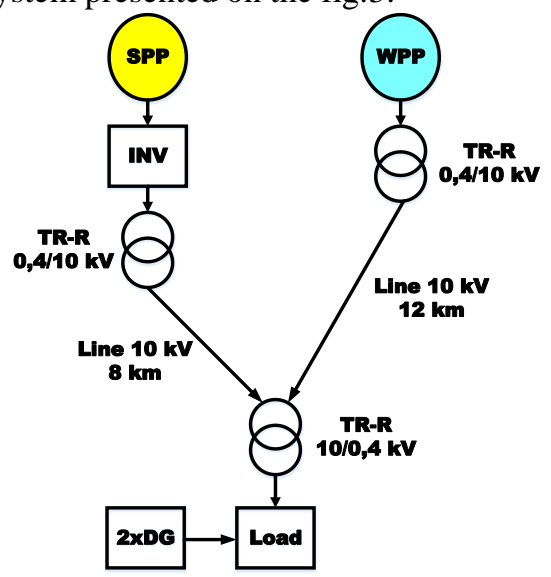

Fig. 3. The scheme of autonomous electric power system

The autonomous power system contains 3 wind power stations with capacity $600 \mathrm{~kW}$ of each, solar power station with total capacity $1 \mathrm{MW}, 3$ transformers, 1 inverter and 2 overhead line with voltage $10 \mathrm{kV}$. Two diesel generators with capacity 1.2 MW of each are emergency sources of electricity in the system. Maximum of electrical load is 1.2 MW. Equipment configuration of the electric power system was earlier optimized.

Reliability analysis is done according the following algorithm.

Step 1. Simulation of random values. Let's $N$ is number of hours of system work. Every hour is characterized of the follow set of random values such as meaning of load, generating capacity and transmitted capacity of power line. The failures of equipment in electric power system are modelled by crash indexes. We suggest to simulate failures of power lines on a base of detailed statistic of crashes of network equipment. Fluctuations of load are simulated through load curve.

Step 2. Estimation of electricity shortage. On this step electricity shortage is estimated for every hour $\mathrm{k}$, $k=1, \ldots, N$. Let's denote the number of all deficited hours through $H$. 
Step 3. Computing of reliability indexes. The probability of non-shortage work of electric power system is computed by the next formula

$$
P=1-\frac{H}{N} \text {. }
$$

Also for reliability analysis other indexes can be used for example the mathematical expectation of electricity shortage.

\section{Experimental research}

For experimental research we used scheme presented of the fig. 3 . We assume that the considered autonomous power system is located in settlement Uzury of Olkhon district. Statistics of failures of overhead lines in the region are presented in [10]. The accident indexes of equipment of the system are shown in $[2,6,10]$. You can see technical characteristics of equipment in [10].

Total number of simulated hours is 100000 for every experiment. Results of reliability analysis for different sets of equipment are presented in table 1.

Table 1. Reliability indexes.

\begin{tabular}{|c|c|c|c|c|}
\hline \multirow{2}{*}{$\begin{array}{c}\text { Set of } \\
\text { equipment }\end{array}$} & \multicolumn{4}{|c|}{ Reliability indexes } \\
\cline { 2 - 5 } & $\begin{array}{c}\text { Table accident indexes } \\
\text { of failures of overhead } \\
\text { lines }\end{array}$ & $\begin{array}{c}\text { Real accident indexes } \\
\text { of failures of overhead } \\
\text { lines }\end{array}$ \\
\cline { 2 - 5 } & $\boldsymbol{P , p . u .}$ & $\boldsymbol{M D}, \boldsymbol{k W h}$ & $\boldsymbol{P}, \boldsymbol{p . u}$. & $\boldsymbol{M D}, \boldsymbol{k W h}$ \\
\hline $\begin{array}{c}\text { Without } \\
\text { diesel } \\
\text { generators }\end{array}$ & 0.23115 & 398.57773 & 0.23093 & 398.40229 \\
\hline $\begin{array}{c}\text { With 1 } \\
\text { diesel } \\
\text { generator }\end{array}$ & 0.99932 & 0.39713 & 0.99925 & 0.39650 \\
\hline $\begin{array}{c}\text { With 2 } \\
\text { diesel } \\
\text { generators }\end{array}$ & 1 & 0 & 1 & 0 \\
\hline
\end{tabular}

As you can see detailed accounting of statistics of failures of overhead lines decreases the probability of non-shortage work of electric power system and the mathematical expectation of electricity shortage. It follows that it is necessary to increase level of detail of initial information and failures data for improving of quality of reliability analysis.

\section{Conclusion}

Detailed accounting of statistics of failures of network and generating equipment is very important for increasing accuracy of reliability analysis. We also took into account detailed climatic arrays, seasons of the year for modelling electrical load, generation regimes and electricity distribution under reliability analysis.

\section{References}

1. Sukyasova E.Yu., Sukyasov S.V., Kornakov K.A. Analysis of trips and injuries in $0,4-10 \mathrm{kV}$ electric networks. Actual Issues of Agrarian Science, 2016, no. 21, pp. 51-54. In Rus.

2. Karamov D.N., Perzhabinsky S.M. Adequacy analysis of electric power systems with wind and solar power stations. E3S Web of Conferences 58, 02019 (2018).

3. Razgildeev G.I., Nogin E.V. Characteristics of distribution grids of power supply system of Kemerovo region. Vestnik of Kuzbass State Technical University, 2009, no. 5, pp. 65-69. In Rus.

4. StatNet. Årsstatistikk 2007-2016 Driftsforstyrrelser, feil og planlagte utkoplinger i 1-22 kV-nettet [The annual statistics provide an overview of errors, interruptions and outcomes during operating disruptions in the Norwegian 1-22kV (for 2006) and the $33-420 \mathrm{kV}$ network]. Available at: http://www.statnett.no/Kraftsystemet/ Nedlastingssenter/Feilstatistikk

5. Kjølle G.H., Aabø Y., Hjartsjø B.T. Fault statistics as a basis for designing cost-effective protection and control solutions. Proc. 2002 CIGRE Session, 2002, pp. 1-6. Available at: https://www.sintef.no/globalassets/project/vern_ko ntroll-ogautomatisering/cigre_2002.pdf.

6. Naumov I.V., Lanin A.V. The analysis of reliability level of rural $10 \mathrm{kV}$ electricity distribution networks (on the example of the eastern branch of electricity networks of the public cooperation on «IESK». Bulletin of the Irkutsk State Agricultural Academy, 2010, no. 40, pp. 115120. In Rus.

7. Razgildeev G.I., Nogin E.V. Failures of overhead transmission lines during thunderstorms. Vestnik of Kuzbass State Technical University, 2011, no. 1, pp. 69-71. In Rus.

8. Karamov D.N. Mathematical modeling of solar radiation based on open access long-term meteorological observation data. Bulletin of the Tomsk Polytechnic University. Geo Assets Engineering, 2017, vol. 328, no. 6, 28-37. In Rus.

9. Karamov D.N. Formation of initial meteorological arrays with the use of long-term series FM 12 Synop and METAR in systems energy studies. Bulletin of the Tomsk Polytechnic University. Geo Assets Engineering, 2018, vol. 329, no. 1, 69-88. In Rus.

10. Karamov D.N., Naumov I.V., Perzhabinsky S.M. Mathematical modelling of failures of electrical grid $(10 \mathrm{kv})$ of autonomous energy systems with renewable distributed generation. Bulletin of the Tomsk Polytechnic University. Geo Assets Engineering, 2018, vol. 329, no. 7, 116-130. In Rus. 